\title{
EQUIPMENT-DEPENDENT NITROGEN LOSS DURING CATTLE MANURE REMOVAL FROM LIVESTOCK HOUSE
}

\author{
Alexander Briukhanov, Ekaterina Shalavina, \\ Pavel Gridnev, Tatyana Gridneva \\ Federal Scientific Agroengineering Centre VIM, Russia \\ shalavinaev@mail.ru
}

\begin{abstract}
The study objective was to establish the patterns of nitrogen loss from manure, when it was removed from the cow houses by different equipment most common in the animal husbandry of North-West Russia. The excrement total nitrogen was calculated by the mass balance method using the actual diet and milk yield data for cows of different lactation phases in a selected cattle-rearing complex. The calculated data were compared with the data obtained experimentally by sampling and analysis in the analytical laboratory. The difference was found to be below $9 \%$. The calculation of manure total nitrogen (ex-housing) included the mass of the added bedding material. In the study, different manure removal equipment was tested under the similar livestock house dimensions, climate control systems, and cow feeding diets - a screw conveyor in Building 1 with the tied animal housing, a scraper system in Building 2 with the loose animal housing, and a TSN-160 scraper chain conveyor in Building 3 with the loose animal housing. According to the study findings, the screw conveyor demonstrated the minimum total nitrogen loss of $7.31 \%$ during the manure removal from the premises. The maximum total nitrogen loss of $32.26 \%$ was recorded for the TSN-160 scraper chain conveyor. The use of the scraper system featured $16.81 \%$ total nitrogen loss. The output of the experimental study was the graphical dependencies of the total nitrogen loss on the distance the manure was moved inside the premises by various manure removal equipment.
\end{abstract}

Keywords: cattle rearing complex, manure, total nitrogen, bedding material, manure removal, equipment.

\section{Introduction}

Cattle excrement is a heterogeneous material that varies by the animal category, age, breed and gender, feeding strategies and animal productivity [1-2]. In Russia, the normative values of the mass and physicochemical composition of animal excrement found in the current valid manure management regulatory guidelines were first defined about forty years ago. They have not been revised since, but are still used in calculations [3-4]. The correct site-specific finding of these values, however, plays an important role when choosing the most suited manure handling technologies and technical means [56]. Improper technological solutions result in the adverse environmental effect, economic costs, and the lost profit from the sale of extra crop yield [7]. The accurate values of the total nitrogen in cattle excrement and manure-based organic fertilizer will optimize the crop rotation-based organic fertilization and, in the end, enhance the environmental sustainability of rural areas [8-11].

Different cattle housing systems have different manure removal equipment, for example, conveyors with the circular movement of the chain with scrapers along the closed contour of concrete canals in the floor (TSN-160), screw conveyors, and scraper systems. Each equipment features specific manure nitrogen loss [12-13]. According to the research results, the proper choice of this equipment and optimisation of its operating modes can reduce the nitrogen loss by up to $50 \%$ $[14 ; 15]$. The most suited manure removal system is placed at the top of the emission abatement measures list [16].

The study objective was to establish the patterns of nitrogen loss during the manure removal from the cow house with different equipment, which is most widely used in animal husbandry in the NorthWest Russia.

\section{Materials and methods}

A typical cattle complex located in the Northwestern Federal District of Russia was selected for the study. The complex specialised in milk production and cattle breeding. The study concerned one animal category, namely cows. All cows were housed in three buildings; each building accommodated the cows of all lactation phases.

The cows received the same feeding rations in accordance with the lactation phase. The weight of the bedding material was the same in all the buildings (Table 1). 
Initial study data of the cattle complex under consideration

\begin{tabular}{|c|c|c|c|c|c|}
\hline \multirow[b]{2}{*}{ Description } & \multirow[b]{2}{*}{ Unit } & \multicolumn{4}{|c|}{ Values } \\
\hline & & $\begin{array}{c}\text { Lactation } \\
\text { phase } 1\end{array}$ & $\begin{array}{c}\text { Lactation } \\
\text { phase } 2\end{array}$ & $\begin{array}{c}\text { Lactation } \\
\text { phase } 3\end{array}$ & Dry cows \\
\hline Lactation phase & day & $1-90$ & $91-210$ & $211-300$ & $301-365$ \\
\hline Feed per cow & $\mathrm{kg} \cdot \mathrm{day}^{-1}$ & 48.48 & 39.2 & 36.9 & 37.24 \\
\hline Feed protein DM & $\%$ & 17 & 16 & 15 & 17 \\
\hline Feed dry matter content & $\%$ & 48.26 & 48.47 & 47.21 & 32.2 \\
\hline $\begin{array}{l}\text { Digestibility of feed dry } \\
\text { matter }\end{array}$ & $\%$ & 72 & 69 & 67 & 68 \\
\hline $\begin{array}{l}\text { Average daily milk yield per } \\
\text { cow }\end{array}$ & $\mathrm{kg}$ & 34 & 25 & 18.5 & 0 \\
\hline Cow housing type & - & \multicolumn{4}{|c|}{ Round the year indoor (stalls) housing } \\
\hline Feed distribution & - & \multicolumn{4}{|c|}{ Mobile devices } \\
\hline Milking technique & - & \multicolumn{4}{|c|}{ Pipeline milking } \\
\hline Bedding material & - & \multicolumn{4}{|c|}{ Saw dust } \\
\hline Ventilation & - & \multicolumn{4}{|c|}{ Natural } \\
\hline Housing system in Building 1 & - & \multicolumn{4}{|c|}{ Tied housing system } \\
\hline $\begin{array}{c}\text { Manure removal system in } \\
\text { Building } 1\end{array}$ & - & \multicolumn{4}{|c|}{ Screw conveyor } \\
\hline Housing system in Building 2 & - & \multicolumn{4}{|c|}{ Loose housing system } \\
\hline $\begin{array}{c}\text { Manure removal system in } \\
\text { Building } 2\end{array}$ & - & \multicolumn{4}{|c|}{ Scraper system } \\
\hline Housing system in Building 3 & - & \multicolumn{4}{|c|}{ Loose housing system } \\
\hline $\begin{array}{c}\text { Manure removal system in } \\
\text { Building } 3\end{array}$ & - & \multicolumn{4}{|c|}{ TSN-160 scraper chain conveyor } \\
\hline
\end{tabular}

The first study step was to calculate the average total nitrogen in the cow excrement by the data from the cattle complex, taking into account the lactation phases and feeding rations [17].

The mass of total nitrogen in excrement per cow was calculated by the formula:

$$
N_{E X}=N_{F}-N_{B}-N_{P}
$$

where $N_{E X}-$ total nitrogen in excrement per cow, $\mathrm{g}$ day $^{-1}$;

$N_{F}$ - total nitrogen in the supplied feed per cow, $\mathrm{g} \cdot \mathrm{day}^{-1}$;

$N_{B}$ - total nitrogen moved from feed to animal body (body gain), g. day ${ }^{-1}$;

$N_{P}$ - total nitrogen moved from feed to the product, $\mathrm{g} \cdot \mathrm{day}^{-1}$.

$$
N_{P}=N_{M}+N_{E}
$$

where $N_{M}$ - total nitrogen in daily milk yield per cow, $\mathrm{g} \cdot \mathrm{day}^{-1}$;

$N_{E}$ - total nitrogen in embryo, g. day ${ }^{-1}$.

The mass of total nitrogen in excrement was recalculated in percentage, taking into account the normative mass of the excrement specified in regulatory documents:

$$
N_{E X}(\%)=\frac{N_{E X}(\mathrm{~g})}{M_{E}(\mathrm{~kg})} \cdot \frac{1}{10}
$$

where $N_{E X}(\mathrm{~g})$ - mass of total nitrogen in excrement per cow, $\mathrm{g} \cdot \mathrm{day}^{-1}$;

$N_{E X}(\%) N_{E X}(\%)$ - total nitrogen content in excrement per cow, \%;

$M_{E}(\mathrm{~kg})$ - mass of excrement per cow, $\mathrm{kg} \cdot \mathrm{day}^{-1}$.

The second step was the sampling of the excrement of cows of each lactation phase in three replications. In each place, the subsamples were collected and mixed into a combined sample, from which a laboratory sample was taken to the analytical laboratory of IEEP - branch of FSAC VIM. 
Overall, 36 laboratory samples of cow excrement were analysed. The total nitrogen in the laboratory samples was determined by the Kjeldahl method following the State Standard GOST 26715-85 "Organic fertilizers. Methods for determination of total nitrogen".

The third step was to compare the calculated total nitrogen content in cow excrement with the experimental values averaged over the three replications (laboratory results). The data from the laboratory analysis protocols were used in the rest of the study.

At the fourth step, the total nitrogen content in the cow manure at the starting point of manure removal was both calculated and determined experimentally. Sampling was carried out in three replications. As a result, nine laboratory samples of cow manure were analysed in the analytical laboratory of IEEP - branch of FSAC VIM.

At the fifth step, the total nitrogen in the cow manure was determined experimentally during its removal from the animal house by three types of equipment - a screw conveyor, scraper system and a TSN-160 scraper chain conveyor. For this purpose, the subsamples were collected at every 15 meters of manure moving distance.

The sixth step was to identify the influence of the manure removal distance by different equipment on the nitrogen loss. It was determined by the difference in the total nitrogen content at the start point of manure removal and a particular sampling point. The average nitrogen content was determined as the arithmetic mean value in the manure samples taken at five different points of the manure canal from the beginning of removal to the unloading point. The maximum manure removal distance was $60 \mathrm{~m}$ for the screw conveyor and the scraper system and $152 \mathrm{~m}$ for the TSN-160 scraper chain conveyor due to the design features of the equipment.

Statgraphics Centurion software package was applied to analyse the experimental data The calculation results showed that the average values fell in the range of standard deviations, therefore, the data were reliable and no suspect data were available. The average values were found within the error range, verifying their reliability.

\section{Results and discussion}

Table 2 presents a comparison of the calculated and experimental data averaged over three replications on the total nitrogen content in the cow excrement.

\section{Calculated and experimental data averaged over three replications on the total nitrogen content in the cow excrement}

\begin{tabular}{|c|c|c|c|}
\hline Sampling point & $\begin{array}{c}\text { Calculated } \\
\text { value, \% }\end{array}$ & $\begin{array}{c}\text { Averaged } \\
\text { experimental } \\
\text { value, \% }\end{array}$ & Difference, $\%$ \\
\hline Building 1, cow lactation phase 1 & 0.64 & 0.59 & 7.81 \\
\hline Building 1, cow lactation phase 2 & 0.56 & 0.52 & 7.14 \\
\hline Building 1, cow lactation phase 3 & 0.51 & 0.47 & 7.84 \\
\hline Building 1, dry cows & 0.78 & 0.71 & 8.97 \\
\hline Building 2, cow lactation phase 1 & 0.64 & 0.6 & 6.25 \\
\hline Building 2, cow lactation phase 2 & 0.56 & 0.51 & 8.93 \\
\hline Building 2, cow lactation phase 2 & 0.51 & 0.48 & 5.88 \\
\hline Building 2, dry cows & 0.78 & 0.72 & 7.69 \\
\hline Building 3, cow lactation phase 1 & 0.64 & 0.6 & 6.25 \\
\hline Building 3, cow lactation phase 2 & 0.56 & 0.57 & 1.79 \\
\hline Building 3, cow lactation phase 3 & 0.51 & 0.5 & 1.96 \\
\hline Building 3, dry cows & 0.78 & 0.71 & 8.97 \\
\hline
\end{tabular}

The difference between the calculated data and the experimental data averaged over three replications was below $9 \%$. This indicated the correct applicability of the mass balance method and generally accepted coefficients for determining the total nitrogen in cow excrement. Since the sampling was a labour and time-consuming process, the experimental determining of the total nitrogen 
content in the cow excrement on large-scale dairy complexes posed certain difficulties. Therefore, an aggregated estimation by the mass balance method was accepted in further investigations.

Table 3 presents a comparison of the calculated and experimental data averaged over three replications on the total nitrogen content in the cow manure (a mixture of animal excrement with process water and bedding material) at the start point and endpoint of manure removal by different equipment.

Table 3

Calculated and experimental data averaged over three replications on the total nitrogen content in the cow manure at the start point and endpoint of manure removal

\begin{tabular}{|l|c|c|c|}
\hline \multicolumn{1}{|c|}{ Sampling point } & $\begin{array}{c}\text { Calculated } \\
\text { value, \% }\end{array}$ & $\begin{array}{c}\text { Averaged } \\
\text { experimental } \\
\text { value, \% }\end{array}$ & Difference, \% \\
\hline $\begin{array}{l}\text { Building 1, screw conveyor - } \\
\text { manure removal start point }\end{array}$ & 0.53 & 0.547 & 3.77 \\
\hline $\begin{array}{l}\text { Building 2, scraper system - } \\
\text { manure removal start point }\end{array}$ & 0.5 & 0.47 & 6 \\
\hline $\begin{array}{l}\text { Building 3, TSN-160 scraper chain } \\
\text { conveyor - manure removal start } \\
\text { point }\end{array}$ & 0.52 & 0.48 & 7.69 \\
\hline $\begin{array}{l}\text { Building 1, screw conveyor - } \\
\text { manure removal end point }\end{array}$ & - & 0.51 & - \\
\hline $\begin{array}{l}\text { Building 2, scraper system - } \\
\text { manure removal end point }\end{array}$ & - & 0.391 & - \\
\hline $\begin{array}{l}\text { Building 3, TSN-160 scraper chain } \\
\text { conveyor - manure removal end } \\
\text { point }\end{array}$ & - & 0.323 & - \\
\hline
\end{tabular}

As follows from the above results, the maximum nitrogen loss during the manure removal was $32.26 \%$, when the TSN-160 scraper chain conveyor was used, $7.31 \%$ - when using the screw conveyor and $16.81 \%$ - when using the scraper system.

Fig. 1 shows the experimental results identifying the effect of the manure removal distance by different equipment on the nitrogen loss.

According to the obtained data analysis, the TSN-160 scraper chain conveyor demonstrated the biggest nitrogen loss along the whole manure removal distance, while the screw conveyor demonstrated the smallest nitrogen loss. This is explained by the conditions and the travelling character of equipment along the manure canal. In the case of the TSN-160 scraper chain conveyor, the canal was uncovered and shallow; the manure layers were actively mixed along the bigger removal distance providing their contact with the environment. With an increase in the removal distance, the nitrogen loss rate decreased due to a decrease in its content in a portion of manure moved.

In the case of the screw conveyor, the canal was deeper and covered with grids; the portion of manure was moved without significant mixing. After 30 meters of manure move, the nitrogen loss rate increased due to the decrease in the manure layer thickness above the flights.

A similar situation was observed, when the manure was removed by the scraper system - when the manure started to fall over the scraper, the nitrogen loss rate increased.

When using the above equipment, there is an opportunity to reduce the nitrogen loss significantly by locating the transverse canal in the middle of the room instead of at the end of it. Thereby the manure removal distance to the endpoint in all cases considered will be reduced by almost twofold. The nitrogen loss will be 62-67 \% lower for screw conveyors and scraper systems, and 20-23\% lower for TSN-160 scraper chain conveyors. At the same time, the labor inputs in manure removal from animal houses, and, consequently, the specific energy intensity of the process, will be almost halved.

The competent use of technologies inside the livestock building, in particular manure removal technologies, can reduce ammonia emissions by $30 \%$ [18]. 


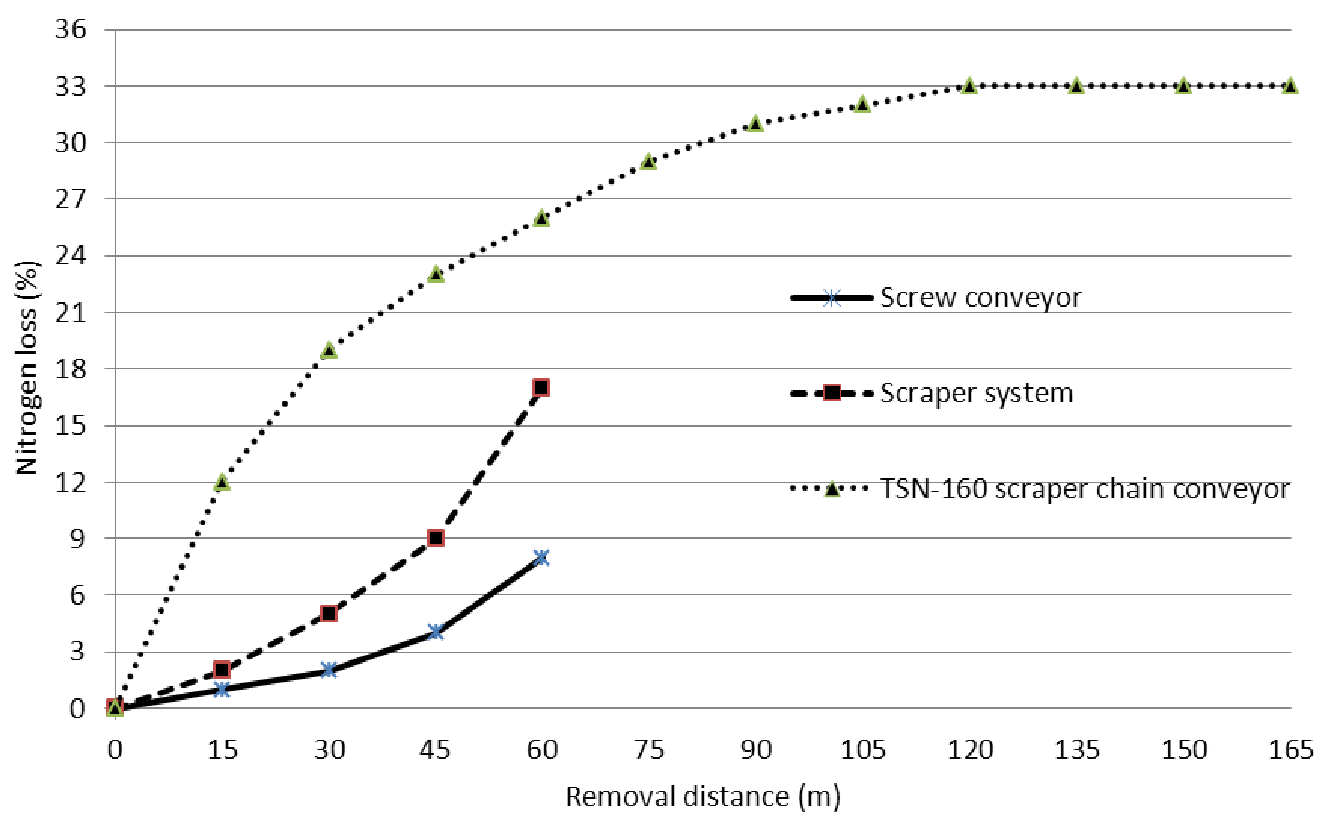

Fig. 1. Effect of the manure removal distance on the nitrogen loss

\section{Conclusions}

The study established the patterns of nitrogen loss from manure, when it was removed from the cow houses by different equipment most common in the animal husbandry of North-West Russia. The study was conducted in three livestock houses with the same dimensions, climate control systems, and cow feeding diets.

The calculated data on the total nitrogen content in the cow excrement were compared with the data obtained experimentally by the laboratory sample analysis. The differences between the calculated and experimental data were below $9 \%$.

The total nitrogen in the manure (cow excrements with bedding material, ex-housing) was calculated taking into account the mass of the added bedding material. The experimental data on the total nitrogen content in the cow manure was obtained for the following manure removal equipment: a screw conveyor, TSN-160 scraper chain conveyor, and a scraper system.

According to the study results, the screw conveyor demonstrated the minimum total nitrogen loss during the manure removal from the premises $-7.31 \%$ of the content in manure at the start point of its removal, the TSN-160 scraper chain conveyor showed the maximum total nitrogen loss $-32.26 \%$, the scraper system $-16.81 \%$.

The obtained graphical dependencies of the total nitrogen loss in manure removal will contribute to the proper choice of most suited manure removal equipment in particular dairy farms.

\section{References}

[1] Aboltins A., Melece L., Priekulis J. Model for ammonia emissions' assessment and comparison of various dairy cattle farming systems and technologies. Agronomy Research 17 (2), 2019, pp. $322-$ 332.

[2] Kaasik A. Relationship between Livestock Nutrition and Excreted Nitrogen and Phosphorus Content. Production of High Quality Products \& Balanced Feeding [online] [03.02.2020]. Available at: www.diva-portal.org/smash/get/diva2:602593/FULLTEXT02

[3] РД-АПК 1.10.15.02-17 «Методические рекомендации по технологическому проектированию систем удаления и подготовки к использованию навоза и помёта» (Management Directive for Agro-Industrial Complex "Recommended Practice for Engineering Designing of Systems for Animal and Poultry Manure Removal and Pre-application Treatment") [online] [20.02.2020]. Available at: http://docs.cntd.ru/document/495876346 (In Russian)

[4] РД-АПК 3.10.15.01-17 «Методические рекомендации по проектированию систем удаления, обработки, обеззараживания, хранения и утилизации навоза и помета» (Management 
Directive for Agro-Industrial Complex "Recommended Practice for Designing of Systems for Animal and Poultry Manure Removal, Treatment, Disinfection, Storage and Utilisation") [online] [20.02.2020]. Available at: http://files.stroyinf.ru/Index2/1/4293744/4293744156.htm (In Russian)

[5] Poulsen H., Lund P, Sehested J, Hutchings N., Sommer S.G. Quantification of Nitrogen and Phosphorus in Manure in the Danish Normative System. In: 12th RAMIRAN International Conference "Technology for Recycling of Manure and Organic Residues in a Whole-Farm Perspective". DIAS Report no. 123. Research Centre Foulum, Denmark: Danish Institute of Agricultural Sciences, vol. II. 2006.105-107.

[6] Sindhöj E., Kaasik A., Kuligowski K., Sipilä I., Tamm K., Tonderski A., Rodhe L. Manure Properties on Case-Study Farms in the Baltic Sea Region. Report 417, Agriculture \& Industry, JTI - Swedish Institute of Agricultural and Environmental Engineering. Uppsala, Sweden. 2013, 80 p.

[7] Брюханов А.Ю., Шалавина Е.В. Анализ образования и накопления животноводческих отходов в Ленинградской области. В сборнике: Экологические проблемы использования органических удобрений в земледелии. Материалы Всероссийской научно-практической конференции с международным участием (Analysis of formation and accumulation of livestock waste in Leningrad Region. In: Ecological problems of organic fertilisers application in agriculture. Proceedings of All-Russian Scientific and Practical Conference). Владимир, ВНИИОУ, 2015. pp. 310-317 (In Russian).

[8] Hristov A. N., Zaman S., Vander Pol M., Ndegwa P., Campbell L., Silva S. Nitrogen Losses from Dairy Manure Estimated Through Nitrogen Mass Balance and Chemical Markers. Journal of Environmental Quality Abstract - Waste Management, Vol. 38, 2009, No. 6, pp. 2438-2448.

[9] Vtoryi V.F., Vtoryi S.V., Ilin R.M. Investigations of temperature and humidity conditions in barn in winter. "Engineering for Rural Development" 17th International Scientific Conference. Jelgava, Latvia, 2018. pp. 265-269.

[10]Клементьева Ю.И. Эффективность использования различных уровней защищенного 1карнитина в рационах высокопродуктивных коров. (The effectiveness of using different levels of protected l-carnitine in the diets of highly productive cows. The dissertation for the degree of candidate of agricultural sciences: Диссертация на соискание ученой степени кандидата сельскохозяйственных наук.) Дубровицы, 2017. 124 p. (In Russian).

[11]Шалавина Е.В., Васильев Э.В. Алгоритм принятия решений при выборе машинных технологий биоконверсии отходов животноводства (Decision-making algorithm when choosing the machine-based technologies for bioconversion of animal waste. Bulletin of AgroIndustrial Complex of Stavropol Territory: Вестник АПК Ставрополья. Vol. 1 (17). 2015. pp. 366-370. (In Russian).

[12] Ковалёв Н.Г., Гриднев П.И., Гриднева Т.Т. Научное обеспечение развития экологически безопасных систем утилизации навоза (Scientific support for the development of environmentally safe systems of manure utilisation). Agricultural Science of the Euro-North-East: Аграрная наука Евро-Северо-Востока, 2016, № 1 (50), pp. 62-69. (In Russian).

[13] Luostarinen S., Grönroos J., Hellstedt M., Nousiainen J, Modeling Manure Quantity and Quality in Finland. Front. Sustain. Food Syst. 2018. 2. p. 60. doi: 10.3389/fsufs. 2018.00060.

[14] Rotz C. A. Management to reduce nitrogen losses in animal production. Journal of Animal Science, Vol. 82, Issue suppl_13, 2004, pp. E119-E137.

[15] Powell J.M., Rotz C.A. Measures of nitrogen use efficiency and nitrogen loss from dairy production systems. Journal of Environmental Quality, 2015, 44. 336. p. DOI: $10.2134 /$ jeq2014.07.0299.

[16] Hartung J., Phillips V. R. Control of Gaseous Emissions from Livestock Buildings and Manure Stores. Journal of Agricultural Engineering Research, Vol. 57, Issue 3, 1994, pp. 173-189.

[17] Overview of calculation methods for the quantity and composition of livestock manure in the Baltic Sea region. Report on current national manure calculation systems. [online] [20.02.2020]. Available at: https://www.luke.fi/manurestandards/wp-content/uploads/sites/25/2019/06/WP3report_ManureStandards_Final2.pdf

[18]Zebarth B.J., Paul J.W., Kleeck R. Van. The effect of nitrogen management in agricultural production on water and air quality: evaluation on a regional scale. Agriculture, Ecosystems \& Environment, Vol. 72, Issue 1 (12), 1999, pp. 35-52. 